\title{
SOMAESTHETICS: A PLEA FOR THE ACKNOWLEDGEMENT OF CONTINGENCY AND BODY IN THE HUMANISTIC EDUCA- $\mathrm{TION}^{1}$
}

\author{
SOMAESTÉTICA: um apelo pelo reconhecimento da contingência e do corpo na \\ educação humanística
}

SOMAESTETICA: un apelo por lo reconocimiento de la contingencia y del cuerpo
en la educación humanística

Aldir Araújo Carvalho Filho

Pesquisador visitante na Florida Atlantic University, EUA (2014-15). Bolsista CAPES. Doutorado e Pós-Doutorado em Filosofia pela Universidade Federal do Rio de Janeiro - UFRJ.

Professor do Colégio Pedro II/RJ.

Professor do Departamento de Filosofia da Universidade Federal do Maranhão - UFMA (cedido). aldir_filho@yahoo.com.br

\begin{abstract}
This article outlines the discussion about the importance of the principle of contingency and the role of the body for education in the humanities, according to Richard Shusterman's neopragmatist philosophy. The background assumption is that it is not possible, for good or ill, to develop any serious approach or inclusive proposal for an enlightened and critical education - especially for philosophy and the humanities - without a mandatory reference to contingency and to the body, one of the most explicit signals of contingency, under the risk of being rendered sterile and useless when confronted with the dynamics brought about by reality. My perspective on Shusterman's work is sympathetic to his change - both in method and academic bias - from a pure analytical point of view to a much more existential approach, which resulted in a new, revolutionary and interdisciplinary field: "Somaesthetics". I sustain that amongst contemporary tendencies Shusterman's ideas represent some of the richest and most exciting contributions regarding the educational possibilities for an integrated human development.
\end{abstract}

KEYWORDS: Somaesthetics. Humanities. Education. Contingency. Body. Richard Shusterman.

RESUMO: Este artigo esboça a discussão sobre a importância do princípio da contingência e o papel do corpo para a educação humanística, de acordo com a filosofia neopragmatista de Richard Shusterman. A hipótese de fundo é que não é possível, para bem ou mal, desenvolver qualquer abordagem séria ou proposta inclusiva para uma educação esclarecida e crítica - especialmente para a filosofia e as ciências humanas - sem uma referência obrigatória à contingência e ao corpo, um dos sinais mais explícitos da contingência, sob o risco de ser tornada estéril e inútil quando em confronto com a dinâmica trazida pelo real. Minha perspectiva sobre o trabalho de Shusterman é simpática à sua mudança - tanto no método quanto no viés acadêmico - de um ponto de vista analítico puro para uma abordagem muito mais existencial, que resultou em um campo novo, revolucionário e interdisciplinar: a "Somaestética". Sustento que, entre as tendências contemporâneas, as ideias de Shusterman representam algumas das contribuições mais ricas e interessantes a respeito das possibilidades educacionais para um desenvolvimento humano integrado.

PALAVRAS-CHAVE: Somaestética. Humanidades. Educação. Contingência. Corpo. Richard Shusterman.

RESUMEN: En este artículo se describe el debate sobre la importancia del principio de la contingencia y el papel del cuerpo en la educación para las humanidades, de acuerdo con la filosofía neopragmatista de Richard Shusterman. La hipótesis de fondo es que no es posible, para bien o mal, desarrollar cualquier abordaje sería o propuesta inclusiva para una educación ilustrada y crítica - especialmente para la filosofía y las ciencias de las humanidades - sin una referencia obligatoria a la contingencia y al cuerpo, uno de los señales más explícitos de la contingencia, con el riesgo de ser estéril y inútil cuando enfrentada con la dinámica provocada por el real. Mi punto de vista sobre el trabajo de Shusterman simpatiza con su cambio - tanto en el método y el sesgo académico - desde un punto de vista analítico puro para un enfoque mucho más existencial, que resultó en un campo nuevo, revolucionario y interdisciplinario: la "Somaestetica". Sostengo que, entre las tendencias contemporáneas, las ideas de Shusterman representan algunas de las más ricas y más interesantes contribuciones respectivamente a las posibilidades educativas para un desarrollo humano integrado.

PALABRAS CLAVE: Somaestetica. Humanidades. Educación. Contingencia. Cuerpo. Richard Shusterman.

\footnotetext{
${ }^{1}$ In Brazil, as in the US, the expression "humanities" has come to a less clear definition than the one it had in its origins, when it was termed as opposed to the "divinities" (as Shusterman explains in one of the articles referred here). If the humanities initially connoted the study of Greek-Roman classics, they now cover arts in general, literature, history and philosophy. The problem now centres on the self-understanding of many "human sciences" that have cultivated a high pretention to be a "scientific" (objective, and not "subjective", "relative") study. Despite this "objectivistic" self-understanding of the "human sciences", both this article and Shusterman's use of the expression take all "non-natural" subjects to be "humanities". See Shusterman (2006, p. 1).
}

Artigo recebido em setembro de 2014

Aprovado em novembro de 2014

Cad. Pes., São Luís, v. 21, n. 3, set./dez. 2014 


\section{1 | INTRODUCTION: PRELIMINARY REMARKS ON AMERICAN PRAGMATISM}

Truth happens to an idea. It becomes true, it is made true by events.

(JAMES, 1907, p. 77)

Despite the commitment of some research traditions, like existentialism, to the sense of historicity and flux of reality - the principle of contingency -, it is possible that in no other modern or contemporary philosophical current this principle plays such a central role and is taken as seriously as in American pragmatism. One of the first consequences of contingency to become visible in pragmatistic research is the significance and scope of philosophical thinking itself. For example, John Dewey (1917, p. 65), probably the most important of early pragmatists, said: "Philosophy recovers itself when it ceases to be a device for dealing with the problems of philosophers and becomes a method, cultivated by philosophers, for dealing with the problems of men". Naturally, we are speaking of problems that arise from the concrete and contingent existence of beings who (re) produce themselves in material and symbolic levels, in several attempting ways, in time and space, living together and facing challenges that are often undesirable and inescapable side effects of their own processes of self-creation.

Even though it is effectively relevant, and despite it was taught in American universities for nearly fifty years since its early stages (although it has never actually been completely dominant or hegemonic), for various reasons, from the 1940s on, pragmatism faced a notable decline, when began the era of the triumphant rise of "analytic philosophy" (a philosophical trend now in advanced stage towards its own twilight ${ }^{2}$.

However, reassuring once more the dictum that history is often ironic and full of unexpected twists, luckily, American pragmatism experienced a strong revival since 1979, when Richard Rorty - a hitherto as "analytic" philosopher as possible - published Philosophy and the mirror of nature. Running a move described by Barnes (2008, p. 1.543) as "a way out of the pragmatist closet," Rorty scandalized the academic institution of analytical orientation, displaying among other things a strong connection of his pragmatism with European philosophers, notably (the "late") Wittgenstein (as it is known that the "early" is often listed as one of the cornerstones of analytic philosophy), but also Heidegger and Foucault (philosophers who widely incorporate the dimension of contingency).

Pouring James' and, in particular, Dewey's ideas in an autonomous mode (a "neo" pragmatism), Rorty, who meanwhile has been considered the most important American philosopher of the second half of the twentieth century, held a successful revaluation of pragmatism, despite some "internal" resistances from, say, "orthodox" pragmatist philosophers . From Rorty on, it seems, the renewal of this tradition is here to stay. Strictly speaking, the new momentum of pragmatism not only has lasted since the late seventies, as has expanded, even involving fields of study other than philosophy. But it is truly important to notice that Rorty was not the sole responsible for the renewed vigour and the growing influence of contemporary neo-pragmatism. Richard Bernstein

\footnotetext{
${ }^{2}$ Actually, it is a shame that in the U.S. philosophical academy after the Second World War a new 'tough minded' spirit engulfed the majority of graduate programs, moving so far away from pragmatist concerns and exhibiting an odd taste for mind games (not much different from chess, for example, except for the pieces are words, not bishops or queens), apparently for the sake of clarity and consistency, but indeed at the cost of no commitment to issues on "everyday life", not to say "reality", and, for extension, on philosophy.

${ }^{3}$ The expression "orthodox philosopher", when applied to pragmatists, speaks against the very sharp program of a mode of though compromised with change and practice, adaptation and transformation. It could almost be seen as a contradiction in terms. In this respect, there should be no "orthodox pragmatist philosopher".
} 
and Richard Shusterman compose with Rorty the "New Constellation" of American pragmatism, forming a diverse but also "a coherent group, engaged in similar arguments, beginning from similar sources, and more or less committed more or less to similar objectives" (BARNES, 2008, p. 1.548).

Unlike Bernstein, who was from the beginning a true blue pragmatist (BARNES, 2008, p. 1.549), but similar to Rorty, Shusterman began his career as an analytic philosopher who only later, around 1988, finally "came out of the pragmatist closet" (SHUSTERMAN, 2000a, p. 17). Just as Rorty had done before, from one point in his intellectual trajectory on, Shusterman let himself be attracted to some of Dewey's main aesthetic arguments, especially his criticism on the mind-body dualism. But contrary to Rorty's dismissal of Dewey's concept of experience, in his own neopragmatist twist Shusterman emphasized the need of handing seriously such a notion. This may explain why the consequences taken by Shusterman from the principle of contingency seem clearly less slippery, so to speak, and more promising than Rorty's, considering the overall consistency. Here, in a very draft mode, I discuss what should be for Shusterman probably the clearest sign of the primacy of the principle of contingency to us all: the dimension of the body. Being something, nonetheless, virtually not detachable from the "mind", it is the body that undeniably affirms what is the human existence about. Therefore, it is almost impossible to speak of "education in the humanities" without an "education for" and, mostly, an "education of" the body.

If we were to compare the positions of Rorty and Shusterman on the theme of contingency, it would become crystal clear that this issue seems to be much more satisfactorily addressed by Shusterman, mostly because the importance this latter attributes to the human body. Indeed, as a natural outcome of the primacy of the body, from a certain point of Shusterman's philosophical development on, emerged the "revolutionary" and "interdisciplinary" field of "Somaesthetics". Then, the motive underlying these very preliminary reflections is quite simple to understand: although an exciting discipline, being as new as it is, Somaesthetics it is still virtually unknown and underappreciated in Brazil . But due to the importance Shusterman's Somaesthetics carry to most different fields of study, mainly philosophy, philosophy of education, education for the humanities, and educational discussions in general, some of its philosophical grounds should be more accurately referred in our Academy. I expect that, by doing so, Shusterman's ideas can, at least, be more easily appropriated by those - intellectuals, scholars, students, public in general - interested in existential issues, education for the humanities, arts, and, mostly, in philosophy as an art of living. This is why it seems to me so important to reassess the premises underlying his discussions on the role and impact of the contingent body over traditional conceptions of philosophy, education and humanities.

\section{2 | SHUSTERMAN'S ACCOUNT OF THE PRAGMATIST PRINCIPLE OF CONTINGENCY.}

Chance is the one essential agency upon which the whole process depends of. Everything that can happen by chance, sometime or other will happen by chance. Chance will sometime bring about a change in every condition. (PEIRCE, 1982, p. 544)

\footnotetext{
${ }^{4}$ There are currently only two books by Shusterman published in Brazil: the first attempt of introducing Shusterman's work in Brazil was Editora 34's "Vivendo a arte", in 1998 (a translation by Gisela Domschke for Pragmatist aesthetics, 1992). The second occurred almost fifteen years later, with "Consciência Corporal" (from Body Consciousness, 2008, translated by Pedro Sette Câmara), published by E Realizações in 2012. Apparently, his books have so far provoked but a little resonance in our academy. There are also some sparse articles, but a complete list is not yet available.

${ }^{5}$ See Shusterman (1997a).
} 
"Contingency", despite being traditionally referred to as the opposite term for "necessity" (a logical pair depicted since Aristotelian metaphysics' as related to the two fundamental modes of existence of the things), in neopragmatist framework means not only a term in a logical pair, but significantly, refers to an ontological, primacial, unavoidable, hence "necessary" condition: nothing escapes time and chance. In this sense, contingency is, thus "not related" to any opposite term whatsoever, and constitutes the - one and only - fundamental mode of being, as it is a framework encompassing all beings, without exception. Therefore, as an ontological principle, it serves to designate the (only) fundamental feature or structure of reality, what makes contingency escape the position of a term in a dichotomy, and become "the" only actual mode of existence. As it includes all entities, human individuals are, of course, involved. And it shall be warned at once that the use of the expression "fundamental" here does not stand for a desire to return to a stage of thought prior to pragmatism ${ }^{6}$. Doing so would appear as the same exact contradiction we see happening to "orthodox pragmatist philosophers".

But in order to get into the heart of the matter, it shall be explicated that fundamental is what necessarily affects human existence, that is, what should be reasonably considered by someone regarding what to do with her own life and how to do it in the most satisfactory, even successful way. Therefore, if contingency is indeed such an inescapable condition, considering adequately its ontological necessity and its various meanings, aspects and consequences - in our case here, the dimension of the human body - is itself an effort in the fullest usefulness and relevance for the self-understanding of human beings, their self-orientation in vital practices and, possibly, for improving their lives by better somatic practices. By virtue of its encompassing pressure on us, contingency is something that human thought and actions have to deal with, even if not aware of it, and despite a Platonism that so renitent and unfortunately has tried from the start to shift the focus of our attention to the dead-end of the "eide" (ideas). In this "new" sense, contingency ends up being, nonetheless, the immovable (though yet totally unstable) "fundament" philosophy always wanted to have ...

Hence, to the extent that human actions occur at and from the scope of contingency, each practical (and theoretical) self-reflection is faced to it as an inherent problem. As Somaesthetics also embraces a philosophy - along with many other disciplines and fields -, one that is engaged with the acknowledgment of the importance of the body and the necessity of the improvement of the soma - the sentient human being -, the presupposition taken for granted here is that Shusterman's philosophy really uses the principle of contingency as a favourable wind towards the perfection of the body and the living with it. That is, instead of treating the contingency factor as a truism needless of attention, he indeed uses it for the empowerment of people, so that contingency can play a beneficial role capable of orientation and practical guidance for the life of soma and it also can work pedagogically for existential, social and political purposes. In suite let us see his deeply rooted commitment to contingency as the fundamental principle of thought and action.

In an article called "What Pragmatism means to me: ten principles", Shusterman (2010, p. 59) has established a list of themes that play "un rôle essentiel dans le pragmatism tel que je le conçois"', principles more or less shared by the leading past and present exponents of the movement. Now, one cannot help but notice that contingency is the first of the chosen themes of

\footnotetext{
${ }^{6}$ After all, pragmatism is the philosophical doctrine responsible for having consistently removed all untenable claims to a "fixed basis," either logical or ontological or epistemological, in the traditional way, even if we cannot yet entirely dismiss the idea of a fixed "reference".

${ }^{7}$ The original paper's abstract is in French.
} 
the list. And it is hard to believe that this has happened "by chance", pardon the pun, despite a strange warning that the principles "[...] appear not in order of the importance I attribute to them, but in the order that seemed best for organizing them for this very brief exposition" (SHUSTERMAN, 2010, p. 60, my italics). emphasis added

Roughly speaking, such a warning could seem to be a cold-water bath on the leading claim in this paper - that there is a central importance of the principle of contingency for the theoretical and practical development of Somaesthetics (as one would reasonably expect it to be). At first glance, this path seemed secluded or dismissed by the very author subject of the research. But one cannot give up so easily, for despite that notice truth is that Shusterman indeed departs from an explicit, crystal clear commitment to the pragmatist principle of contingency. In that article he introduced the theme of contingency while referring to the first principle of pragmatism, "the mutant and open nature of reality":

\begin{abstract}
The world that we know through human experience is a world without absolute fixity or permanence. Not only our personal experience but the external world is a world whose regularities and stabilities exist in a framework of change, much of which is not noticed. Even our images of permanence, such as mountains, are the products of change and continue to change through erosion and other natural and human forces. Contingency means that chance is an integral part of life, that behavioral and social processes and even natural laws are matters of probability rather than of absolute necessity that admits of no surprises, exceptions, or aberrations. (SHUSTERMAN, 2010, p. 60).
\end{abstract}

Therefore, one good possibility for his choosing it to be the first in the order of exposition is because it indeed is the very first principle for pragmatist thinkers in general. And perhaps this is so due to a strong reason. Contingency bears a special asymmetry to the other pragmatist principles: out of the ten listed by Shusterman, this is the only one that refers to the "nature of reality", or to how reality "is", while the other nine are principles stemming from "our friction with reality" ("experience", perhaps), or yet, referring to how we do (or should) behave in face of reality. Because of that, there are many elements leading us to the recognition that if there is a candidate-principle to play a central role in the development of Shusterman's aesthetic pragmatism this will surely be ... contingency.

Anyway, without trying to impose a heavy hand on the matter, and recalling how exploratory these reflections are, for now it would be enough if we keep open to the possibility that our claimed hypothesis is fruitful and far from being pointless. For we have just had a glimpse that when trying to put things together from a clear point of departure, in a consistent fashion, one will always be confronted with contingency. It is where lies its "preeminent force" on us. Of course, we are not supposed to deny the fourth pragmatist principle - the anticartesianism -, for we are no longer forever cursed to follow a Gueroultian/Cartesian "necessary order of reasons", for the sake of "philosophical demonstration" (whatever this may be). We can perfectly combine the first and the fourth principles because it really does not matter in which order the principle of contingency comes displayed in pragmatist's considerations: more than being the "first", it is the "central" one, because it is the only one thing that cannot be avoided ...

The poetic passage in which Shusterman depicted the principle of contingency carries beauty as well as sufficient persuasive force on what is most important to the question. His description shows pragmatism as the most suitable philosophy for making us understand and accept that contingency is indeed inevitable. This is why pragmatist philosophers, at least the early ones, 
[...] Clearly influenced by Darwin (... shared) a belief in the importance and role of radical contingency, as well as recognition of the need for adaptation in the face of unpredictability (...) Humans should always expect the unexpected. For this reason Dewey argued for cultivation of a "reflective intelligence, that is, a willingness to change our mind". (BARNES, 2008 , p. 1.545, my italics).

Though it is quite reasonable that Shusterman's description of contingency highlights, as it should be, the emphasis pragmatists, including himself, give to "Tychism"8 (i.e., from above, the belief in the importance and role of radical contingency), he also considered extremely important to note that "contingency/fluent reality" is not incompatible with the existence of "regularities". The perception of such regularities, like the waves of an ocean, are what make possible, in some way, cognitive behaviour, intelligent reaction and practice of men faced to the challenge of building their lives (i.e., from above, recognition of the need for adaptation in the face of unpredictability). The ability to respond adaptively allowed our animal species to build "culture", a set of tools for dealing with reality in a human way, including the scientific method / science, but also art and philosophy. Like Dewey, Shusterman emphasizes the element of "reflective intelligence" that we need for better dealing with reality. In this sense, as a matter of fact, the eighth pragmatist principle - the meliorism - implies a commitment not only to adaptation, but also to improvement.

For this reason, it makes perfect sense that although radical contingency is clearly highlighted it is not done in a way to lock nihilistically any initiative for improvement. And it also makes sense to indicate that while having an important and central role it shall appear "balanced" with other pragmatist principles, in particular the belief in the utility of scientific knowledge, for the sake of human purposes and values. According to Shusterman, the point is that pragmatism cannot be taken, not even eventually (safe mistakenly?), as leading to a kind of "passive nihilism" or to any other type of vital, moral and spiritual negative path or mood. The underlying premise seems quite clear: what would be the meaning of a productive engagement in activities such as science, art or philosophy if one cannot act according to any regularity, that is, if one can not learn from it and play an active part in shaping the changes? What's the use of culture, if not to interfering with the social and natural world? Hence, the emphasis on cognitive / rational abilities of human beings is clearly intertwined with the idea that "the open and malleable nature of the world, moreover, encourages the idea of freedom for positive action that can make a real difference" (SHUSTERMAN, 2010, p. 60).

By pointing out fallibilism (an adequate theoretical account to deal with radical contingency), another pragmatist's most valued element that cannot be confused with scepticism, Shusterman insists that the results of it for philosophy are the overcoming of images of essentialist fixity, and along with science and other cultural instruments, the manifesto for an active engagement to change the world:

A further consequence is that philosophy, as a human activity that engages with the changing world, can also help to change it. In this sense, pragmatism supports the idea that philosophy should engage not only with concepts, but also in praxis. (SHUSTERMAN, 2010, p. 60).

Thus, instead of taking the principle of contingency as something leading to relativism (actually a foolish idea), and instead of running the major risk of considering it a void truism, pragmatism

${ }^{8}$ From Greek tyché (chance). "Tychism" is Peirce's doctrine of "absolute chance", or "the doctrine that understands chance as a real ontological element, and not merely a product of human ignorance." See Salathiel (2008, p. 10). 
brought about the principle of contingency as its prime differential element from other modern philosophical conceptions, and especially to remind us all about this: the idea of chance and change must accompany every (important) human decision for action, because not doing so implies loosing the chance to dealing with reality itself. Looking to the future is one thing. Dreaming in a vacuum is another. Much more than to the concepts, contingency holds an enormous importance to praxis. Its acknowledgment must conduct us to act in a full range of considerations, moreover the ones that include the bodily ones. And this is what Somaesthetics is about, as Shusterman tries to recover "the physicality of the body, the neglected topic of pragmatism" (BARNES, 2008, p. 1.550).

\section{3 | DIVING INTO THE SOMATIC DIMENSION: the practicality of philosophy.}

In his own neopragmatist turn, we have seen that Shusterman assumed a preferential option for contingency and "practice". Those are assumptions shared by early pragmatists - not just in what regards to anti-foundationalism and anti-essentialism, but also to the social character of the practice. However, it should be noted that his journey "back to the roots" is not intended to resume an intention laying behind American pragmatism alone, 'cause after all pragmatism is a philosophy developed in the last hundred and fifty years. Shusterman's concerns and criticisms actually target a much earlier time: the origins of philosophy itself. In the so far most known companion to Shusterman's work, we can find a clear defence of this line of interpretation:

In fact, Shusterman's plea for the practicality of philosophy should be seen not only as an attempt at reinvigorating the spirit that permeated the thought of his hero John Dewey, but also as an explicit return to the long forgotten ancient conception of bios philosophicos, which has been recently excavated by a host of authors, including Pierre Hadot, Michel Foucault, Martha Nussbaum, and Stanley Cavell. (MALECKI, 2010, p. 19)

The choice for practicality guiding Shusterman's theoretical efforts is orientated towards the search for a reflective (pragmatic) mode to dealing with radical contingency, and that involves trying to give affirmative answers to traditional (and more fundamental) questions, such as: "How should I live?" According to Shusterman, whatever the answer to this question may be, it can only be given by a live human / physical / mental body or a "soma" - the compound/complex sensitive, intelligent, sentient human body. Abandoning the traditional Cartesian "mind/body" dichotomy, the notion of soma is a much larger, better and suitable idea to relate to a concrete human integral existence, lived in and by an individual, physical/mental body/mind. We should see that as a pretty fine outcome of an initially analytic aesthetics that turned to be a pragmatist aesthetics and, in the need for further development, had to recreate itself as a brand new "cross-over" field: Somaesthetics, namely the "aesthetics and ethics of the soma."

Such self-understanding can be found in the very Author's Preface to Thinking Through The Body. Essays in Somaesthetics, Shusterman's latest book:

Adopting the pragmatism my new philosophical direction meant rediscovering the pressing existential issue that first drew me to philosophy and that first defined philosophy in ancient times: the question on how one should live. The idea of the philosophy as an art of living aimed at realizing beauty through creative intelligence and critical reflection (involving both aesthetic and ethical sensitivity) thus formed the topic of my subsequent book, Practicing Philosophy: Pragmatism and the Philosophical Life (1997), the first English publication in which I proposed the idea of somaesthetics. The project of somaesthetics evolved as the logical consequence of my arguments advocating pragmatist aesthetics and the phil 
osophical life. As art cannot be created or appreciated without using our bodily senses, actions, and experience, so our lives must inevitably be lived somatically. If we wish to improve our lives (and not only by improving the arts and aesthetic experience that enrich our lives), then one important way to do so would be to improve our understanding and mastery of our bodies - the fundamental, indispensable instrument or medium through which we perceive, act, and live this life on earth. As there seemed to be no field explicitly designed to develop this improved somatic understanding and mastery, somaesthetics thus emerged for me as an essential project, one to which I have since dedicated most of my research efforts. (SHUSTERMAN, 2012a, p. ix-x)

When considered the philosophical density of this passage, we can now come to the centre of this text, that is, the need to discuss the importance of the body for education in the humanities. For we can now see that, in its core aspects, Somaesthetics is an account of the states of things that seems ready to endorse the very fundamental assumptions underlying any educational conception or enterprise, regardless of its ideological aspects: I) It is possible for the human being to choose / determine / create the specific quality of the experience of each moment, and assign for each one its meaning(s); II) It is possible to organize the meanings of lived moments in a kind of "global sense" of life itself. In short, one's ability to respond well and beautifully to the possibilities referred in assumptions (I) and (II) is what has long been termed as art of living. For Shusterman, if philosophy has anything to say to the humanities, it has to do so from the inside of these considerations. But first, it needs to draw real attention to the body. That is a notion - and also a value - constantly and systematically neglected in the tradition and, naturally, in education in the humanities, as we shall see next.

\section{4 | ACKNOWLEDGING THE BODY: a plea for Somaesthetics.}

In an article originally given as his inaugural lecture as the Dorothy F. Schmidt Eminent Scholar in the Humanities at Florida Atlantic University, April 6, 2005, Boca Raton, USA, Shusterman took a striking point of departure to address his neopragmatist criticisms to traditional approaches of the education in the humanities:

[...] it is clear (even from etymology) that the meaning of the humanities essentially relates to our human condition and our efforts to perfect our humanity and its expression. But what, then, does it mean to be human? I cannot pretend here to adequately answer such a complex and difficult question. I will, however, argue that because the body is an essential and valuable dimension of our humanity, it should be recognized as a crucial topic of humanistic study and experiential learning. Though the truth of this thesis should be obvious, it goes sharply against the grain of our traditional understanding of the humanities. One striking example of such antisomatic bias is the very term that German speakers use to designate the humanities, "Geisteswissenschaften," whose literal English translation would be "spiritual (or mental) sciences," as contrasted to the natural sciences (Naturwissenschaften) that treat physical life, with which, of course, the body is clearly linked. Hence, given the pervasive physical/spiritual opposition, the body is essentially omitted or marginalized in our conception of humanistic studies. (SHUSTERMAN, 2006, p. 1-2, my italics).

Taking a hard ground on contingency as he does, it is quite reasonable that the somaesthetics theorist and, mainly, the pragmatist educator Shusterman be worried about the true obstacles to human development posed by traditional education focused on the "mind". That is why that entire article is dedicated to make a plea for the acknowledgment of the "embodied circumstance" that is our lives. The body is "the tool of tools" and we no longer can perfection our skills or live better 
without a deep, proper and respectful knowledge - both theoretical and practical - on the human body. It is to be noted that the human body is already a serious and valuable subject of the study of many "natural sciences", but, because of some unattended factors, constantly neglected in the humanities. Therefore, in a certain way, one of the goals of Somaesthetics is to become a breezeway, an open and transiting space between the "hard" disciplines on the body and all philosophical, humanistic, artistic and the like studies, concerning the deepest knowledge and education possible for and by the body. This is also why Shusterman coined the expression "thinking through the body" in the very title of that article, in a way to stress the importance that humanistic education has respect to the constructive cultural dimension of a bodily existing humanity. If this is so, humanistic intellectuals and teachers can no longer stick to the "mind" (say, the "reason"?) as the sole locus of our humanity. Therefore, a big portion of the article (which later turned out to the same title lengthy and detailed book aforementioned) is dedicated to a diatribe against this silly reduction of mankind to the (allegedly) "mental" dimension, despite of the bodily one.

Of course, the reduction is not without causes. Hence, for Shusterman it would be important to point out the motives behind the resistance in the humanities to treat the body in a proper way: "[...] before saying more about somaesthetics, I want to explain and challenge this resistance. I will argue the paradoxical thesis that the body has been rejected in the humanities precisely because it so powerfully expresses the fundamental ambiguity of being human" (SHUSTERMAN, 2006, p. 3 , my italics).

By "fundamental ambiguity" Shusterman enlisted many things. The first one is our double status, as object and as subject. Linked to this, for instance, is the notorious devaluation the canon Plato/Kant has ever practiced over the body. But also the far more common experience of feeling "disassociated" with my own body, as I "am" a body and at the same time I "have" a body that sometimes I do not even recognize as "myself". All of this speaks of a "weakness" of the bodily condition of mankind. And, of course, it frightens us all. But it would be strikingly necessary to surpass this fear, in our own benefit.

Another ambiguity is that fact that our body expresses both the characteristics of a shared species and of an individual being with her difference. Actually, we should speak in differences: genders, ethnicities, classes, cultures, languages, values, shapes and colours. For each one of us bear unique features that are mostly recognized by our bodies, more, perhaps, than by our "minds". Anyway, being or having a body has been a constant source of "torment" for the specific predominant cultural identity forged by "Western Civilization", based on the value of the "spirit" in the "body" (as "box" or as "coffin"):

The body exemplifies our multiply ambivalent human condition between power and frailty, worthiness and shame, dignity and brutishness, knowledge and ignorance. We invoke the notion of humanity to urge a person toward moral excellence and rationality that transcend mere animality, but we also use the predicate "human" to describe and excuse our flaws, failures, and lapses into base or even bestial behavior: they are human weaknesses, limits linked to the frailties of the flesh we share with common beasts. (SHUSTERMAN, 2006, p. 5).

Since Paul Apostle, at least, Christianity has seen the body as the enemy of righteousness. Upon such ideologies of domination, social, cultural (theoretical-discursive hence eminently practical) mechanisms have been used to covertly materialize and preserve norms, values and behaviours by encoding them in somatic inscriptions and bodily habits, dissimulated as the "proper" conduct, so to escape critical consciousness. Only this would be a fair, clear reason for a critical education to be focused on the very study on the social uses of the body and its "disciplinary" en- 
codings. Indeed, having been supervised by Bourdieu in some post-doctoral studies, and being also a commentator on his work ${ }^{9}$, Shusterman is quite aware that scholars like Foucault and Bourdieu are strongly in favour of an embodied approach in the humanities. But this a very recent path, that must be widened and linked to the education of the individual not only in a critical but, also, in a constructive way:

\begin{abstract}
If the body captures the ambiguous human condition of subject and object, power and vulnerability, dignity and indignity, freedom and constraint, commonality and difference, knowledge and ignorance, why does modern humanistic philosophy tend to take the positive sides of this ambiguity for granted and negatively marginalize the body by emphasizing its weaknesses? Part of the reason is our profound reluctance to accept our human limitations of mortality and frailty, which the body so clearly symbolizes. Though the field of humanities was first introduced in contrast to theological studies termed divinity, humanist thinkers do not seem content to be human; they secret want to transcend mortality, weakness and error, and to live like gods. Since body life does not allow this, they focus on the mind. (SHUSTERMAN, 2006, p. 8).
\end{abstract}

Again, comes the urge for a renovated meaning of the educational task for, after all, what is education about, if not of bringing men and women to their best possibilities? In this sense, a "critical" dimension of education is justified and required if and only if it is suited to build a better pavement for mankind achievements. Education has to be a cultural tool for overcoming any form of domination, and that includes the superpower of the ideology of the "weak body, strong mind". Otherwise, what would it be needed for?

\title{
5 | CONCLUSIONS: learning and teaching from the soma for a better life.
}

Of course, when it comes to the most difficult questions of all, that is, the ones concerning our learning or acquiring expertise on how to "react" to contingency, how to respond "appropriately" - even artistically and creatively - to the changing flow of our experiences, a very preliminary problem arises: an experience - or, as Shusterman points out, an "act of the body" - requires a performance "now". To this "immediateness" of the act it is unlikely to be of much help any "analytical" predisposition, for the simple reason that when "reason" comes, most of all the moment is long gone... If every moment of life can ask (and often does) a different response, how can one be fully prepared for it in advance? How to be prepared for the unexpected? Apparently, taking care of itself implies a kind of focal attention that cannot be postponed by "reflection", except if the moment is thematically dedicated to it, i.e., when the experience is the reflection itself. But it does not make any sense these days to imagine, like Aristotle once did, that the best of life is just "reflection". After pragmatism, and especially after Shusterman's pragmatism, bios philosophicos cannot be identical to bios theoretikos. Therefore, how can we foster somaesthetical learning in the face of challenges posed by radical contingency, a condition that asks of us the most various performances and for which we are almost never ready?

Here's a good initial response:

The basic somaesthetic logic here (also affirmed by other Greek thinkers) is that rather than rejecting the body because of its sensory deceptions, we should try to correct the functional performance of the senses, by cultivating improved somatic awareness and self-use, which can also improve by giving us greater perceptual sensitivity and powers of action. (SHUSTERMAN, 2006, p. 8). 
This is the belief underlying the efforts - fully valid and increasingly necessary - to understand and deepen reflection of our way of doing things but, mostly, of doing education, which are all performed by the "soma". This is all about the process of training, practice, performance and the development of somatic habits, in a word, the education, the mastery of the body-mind. Something like believing that we can learn to sail after waking up on a boat already launched in a vast, sometimes sunny, at times misty and often tormented sea. Of course, without the proper study, one could easily mistake Somaesthetics for a doctrine only concerned about "gymnastics" or, maybe, only focused on (necessary though not exclusive) "thanatological meditation". For when talking about a revival of philosophy as an art of living, one could imagine it as only a contemporary echo either for a fixation in bodily sensations for pleasure/pain accuracy or for an important philosophical practice that has existed freely since a very long time: the counselled exercise of meditation on the brevity of life and the proximity of death ${ }^{10}$. Sure, the brevity of life is still the same as always and, still more certain is the fact that contemporary mood for bodily fixations runs away from meditating about it like it was running from the devil. But Somaesthetics is strictly neither one, nor the other, as it has to do with a positive - not positivistic - attitude towards body, mind, life and death: the virtuous self-creation and mastery of the soma.

A life lived virtuously possesses a deep analogy with a work of art virtuously created. Thus from that also emerges the deepest aiming of education, that is, the integrated development of human possibilities: we educate ourselves along with our students by virtuously creating our knowledge, values, practices and shared moments. And we are now sure why this process has to imply the deepest acknowledgment of contingency and body: "Transcendence [...] need not be interpreted in supernatural terms. Our very being is a flux to become something else, which can be constructively construed in moral terms of self-improvement" (SHUSTERMAN, 2006, p. 8, my italics).

\footnotetext{
${ }^{10}$ What was a must in refined spirits until two centuries ago has meanwhile, mostly due to the positivistic spirit, turned to be out-dated.
} 


\section{REFERENCES}

ARISTOTLE. Retórica. 2. ed. Translation and notes by Manuel Alexandre Júnior, Paulo Farmhouse Abel do Nascimento and Alberto Pena. Lisbon: National Press; Mint, 2005. (Collection "Classic Authors Library" Works of Aristotle).

BARNES, T. J. American pragmatism: towards a geographical introduction. Geoforum, v. 39, p. 1.542-1.554, July 2008.

BERNSTEIN, R. J. The resurgence of pragmatism. Social Research, v. 59, p. 813-840, Dec. 1992.

DEWEY, J. et al. Creative intelligence: essays in the pragmatic attitude. New York: Henry Holt and Company, 1917.

JAMES, W. Pragmatism: an old way for some new ways of thinking. New York: Longmans \& Green, 1907.

MALECKI, W. Embodying pragmatism: Richard Shusterman's philosophy and literary theory. Frankfurt am Main: Peter Lang, 2010.

PEIRCE, C. S. In: FISCH, M. H. (Ed.) Writings of Charles S. Peirce: a chronological edition. Bloomington: Indiana University Press, 1982. v. 6.

RORTY, R. Philosophy and the mirror of nature. Princeton: Princeton University Press, 1979.

SALATHIEL, J. R. Sobre o conceito de acaso na filosofia de Charles S. Peirce. 2008. Thesis (Doctor Degree in Philosophy) - Catholic University of São Paulo, São Paulo, 2008.

SHUSTERMAN, R. Aesthetics between nationalism and internationalism. The Journal of Aesthetics and Art Criticism, v. 51, n. 2, p. 157-167, Spring 1993.

Practicing philosophy: pragmatism and the philosophical life. New York and London: Routledge, 1997a.

Internationalism in philosophy: models,

motives and problems. Metaphilosophy, v. 28, n. 4, p. 289-301, Oct. 1997b.
. The self as a work of art. The Nation, p. 25-28, June 30 1997c. Review of Rabinow, P. (Ed.) (Essential works of Michel Foucault, 1954-1984: Ethics: subjectivity and truth, v. 1).

Somaesthetics: a disciplinary proposal. The Journal of Aesthetics and Art Criticism, v. 57, n. 3, p. 299-313, Summer 1999a.

Bourdieu: a critical reader. London: John Wiley Trade, 1999b. (Blackwell Collection).

Pragmatist aesthetics: living beauty, rethinking art. 2. ed. New York: Rowman \& Littlefield, 2000a.

Performing live: aesthetic alternatives for the ends of art. Ithaca: Cornell University Press, 2000b.

Somaesthetics and care of the self: the case of Foucault. The Monist, v. 83, n. 4, p. 530-551, 2000c.

Intellectualism and the fields of aesthetics: the return of the repressed? Revue Internationale de Philosophie, n. 220, p. 327-342, 2002-2.

Somaesthetics and education: exploring the terrain. In: BRESLER, L. (Ed.). Knowing bodies, moving minds. Amsterdam: Kluwer, 2004. p. 51-60.

Thinking through the body, educating for the humanities: a plea for somaesthetics. Journal of Aesthetic Education, v. 40, n. 1, p. 1-21, Spring 2006.

What pragmatism means to me: ten principles. Revue Française d'Études Americaines, n. 124, p. 59-65, 2. trim. 2010.

Thinking through the body: essays in somaesthetics. New York: Cambridge University Press, 2012a.

Consciência corporal. Translated by Pedro Sette-Câmara. São Paulo:

Realizações, 2012b.

Affective cognition: from pragmatism to somaesthetics. Intellectica, n. 60, p. 49-68, 2013. 